\title{
"The Joy of Reading" - An Intervention Program to Increase Reading Motivation for Pupils with Learning Disabilities
}

\author{
Esther Tovli ${ }^{1}$ \\ ${ }^{1}$ Department of Education, Shaanan Collage, Haifa, Israel \\ Correspondence: Esther Tovli, Department of Education, Shaanan Collage, Haifa, Israel
}

Received: June 24, 2014 Accepted: July 7, 2014 Online Published: August 21, 2014

doi:10.11114/jets.v2i4.496 URL: http://dx.doi.org/10.11114/jets.v2i4.496

\begin{abstract}
This study aimed to examine the effect of an intensive reading intervention on reading motivation. The intervention program, ("Joy of Reading"), was implemented in six $2^{\text {nd }}$ grade special education classes for pupils with learning disabilities, compared to a control group ( $\mathrm{n}=108$ pupils in total).

The intervention program was created based on learning principles that were proven effective among children with learning disabilities, included intensive exposure to daily structured reading activities, encouraging pupils' involvement in various reading and writing activities. The reading activities included traditional children's literature from all over the world, exposing the pupils to different cultures while being sensitive to their own cultural values. Additional components, such as systematic exposure to schema story discourse, linguistic enrichment and social values, were added through various activities.

At the end of the school year, both groups were assessed (the intervention and control groups) using three measures: Book preference, Quality of reading and Quantity of reading.

The results indicate a significant difference between the intervention group and the control group in all three measures, confirming the hypothesis that intensive, systematic and structured exposure to reading helps pupils with learning disabilities adopt reading habits as an enjoyable way to spend time. The results also show a relatively more active reading routine is established enabling the improvement of readers' ability to reconstruct stories, analyze what they read, recommend it to their peers, and explain their choice
\end{abstract}

Keywords: Joy of reading, Quantity of reading, Quality of reading, Reading motivation

\section{Introduction}

Reading books and stories is central to human development (Witt, 2000). An initiated and planned action wasn't necessary in the past in order to make the book "A child's best friend", but nowadays the notion of "where has the love of reading gone?" is dealt with on a daily basis by leading educators and educational policy makers (Epstein \& Yanai, 2011).

The steady decline in children's motivation to read is a serious phenomenon, which might fundamentally change the way children of the current generation deal with language (Clark \& Akerman, 2006; Levin \& Aram, 2012). It is thus evident that tackling this phenomenon requires programs that increase reading motivation among children (Memis \& Bozkurt, 2013). One of the natural ways to enhance reading is through stories (reading, telling, retelling, acting, etc.). Accordingly, it is not coincidental that the story is a central element in the language curriculum in many countries (Blum-Kulka et al., 2003). The main aim of the curriculum is to foster a literate person, who masters the language and loves books, enjoying original and translated texts. This conception matches current approaches towards reading literacy (Gambrell, 2011; Mullis et al., 2007).

In spite of its importance there is a growing concern about the lack of reading habits among the young generation. This study presents an intervention program that promotes reading enjoyment. The intervention is based on four guiding principles: structure, time investment, consistency and choice, whose purpose is to lead reluctant readers towards reading enjoyment. First, we shall present a short review about the contribution of stories and books to children's literacy and then we shall proceed to reading enjoyment, these two components being the basis of the reading intervention presented in this study. 


\section{Literature Review}

In the literature review, we highlight six key elements of the benefits of story reading: (1.1) The contribution of the book and story to the listener and the reader, (1.2) National themes, cultural and artistic values. (1.3) Written language versus spoken language. (1.4) Story, book and socio-economic positioning. (1.5) Increasing reading motivation of children with learning disabilities. (1.6) The intervention program: "The Joy of Reading".

\subsection{The Contribution of the Book and Story to the Listener and the Reader}

\section{"The brain is a story-seeking, story-creating instrument"(Smith, 1990, p.6).}

It seems that reading, besides its obvious contribution to the development of language, values, and social and cultural codes, also offers potential growth points for the development of a more subtle awareness of human behavior (Dungworth et al., 2004; Clark \& Foster, 2005).

One way to make sense of our world is by creating our own stories and by understanding others' stories (Gambrell, 2011). Children hear and create stories from a very young age, developing this skill as they get older (Mol \& Bus, 2011). Therefore, the book and the story have a significant contribution to a child's development. Exposure to stories, told or read, enables the child to build a schema discourse story (Berman, 2009). The experience of story genres at school has several combined roles: it exposes the students to different story structures, and to a large variance of narrative sub-genres, and enables them to improve their ability to build oral and verbal story texts. The story experience connects children to their own culture and to other realms and prepares them for their future participation in these worlds (Mol, Bus \& de Jong 2009).

\subsection{National Themes, Cultural and Artistic Values}

Israel is a country of immigrants; therefore, exposure to stories enables the reader or listener to become acquainted with new cultures while retaining his/her own culture and values from home in the new environment.

The story's power expresses itself in various ways, through philosophic ideas and aspects that convey values and national themes of the society in which the child lives (e.g. the "ingathering of the exiles" in Israel). These include cultural and ethical themes, such as customs and exemplary persons and such humane universal themes as righteousness, honesty, charity, compassion and mercy (Levin, 2007). This power is also present in the educational and psychological opportunities where the children's needs express themselves by bridging between the need for social belonging and the difficulties involved in conformity; mediating between the need for security and love and the anxiety felt in their absence; bridging between the intimate personal revelation and the social, national and universal one. The story's strength also manifests itself in literature and artistic aspects, in which the present is at the center of the child's life; and in "let's pretend" games in the literal reality he/she enters. It is also a way to re-design a harsh reality in a refined way that creates opportunities for growth and development.

Therefore, by exposing children to stories, they meet the classical and universal literature, as well as the national one, various artistic means and modes of expression creating their personal Israeli-Jewish and universal cultural identity.

\subsection{Written Language versus Spoken Language}

One of the book's central contributions to literacy is in developing linguistic abilities. Exposing children to the linguistic form of books, by listening to a story or reading it, contributes in a significant way to their language. The book's vocabulary is richer than the spoken one. The structural syntax that characterizes the book's language is much more complex than that used in the spoken one. In the spoken language, children might omit parts of sentences, while in the written one they will usually encounter the complete and proper form of the sentence Therefore, it seems that reading books to children serves as a stimulus to their cognitive development and makes a significant contribution to their linguistic abilities (Clark \& Rumbold, 2006).

\subsection{Story, Book and Socio-Economic Positioning}

Research shows that children's written language acquisition is anchored in the cultural-social context in which they grow up (Clark \& Akerman, 2006; Serpell, Baker \& Sonnenschein, 2005). Children from low socio-economic status live mostly in environments where there are fewer guided opportunities for literacy exposure, with fewer books at home, less listening and participating in story-telling, fewer library visiting events, etc. (Bus, van Ijzendorn \& Pellegrini, 1995). Hence, children from lower socio-economic status start school with lower literacy assets, which means that the school needs to close these gaps (Mol \& Bus, 2011).

How can these gaps be minimized? Allington et al. (2010) demonstrated the effectiveness of a 3-year intervention program for children from low socio-economic status in increasing reading motivation and language skills. 


\subsection{Increasing Reading Motivation of Children with Learning Disabilities}

Among young readers, reading motivation relates to "interest in reading" (Guthrie \& Wigfield, 2000), which is expressed in the reader favoring reading books over other activities. The young readers read more frequently, and enjoy reading. Therefore, young readers with high reading motivation enjoy reading, read frequently (Wang \& Guthrie, 2004), and express a personal preference for reading (Guthrie \& Wigfield, 2000).

The problem of reading motivation becomes more significant when learning disabilities and reading difficulties enter into the equation. In Israel, "A person is diagnosed as 'learning disabled' when his/her achievements on standardized tests of reading, math and written expression... are significantly lower than expected for his/her age and IQ level." (Israel's Ministry of Education, 2000, p.28) Research indicates that reading enhances cognitive processes related to reading comprehension (Aram \& Levin, 2002), but children with learning disabilities, who read much less, miss out on the gains of reading.

Several intervention programs which aim to increase reading motivation among pupils with learning disabilities were previously studied. Zentall and Lee (2012), for example, demonstrated an intervention program which was proven effective in improving reading motivation, fluency and comprehension for the reading-disabled group, with and without attention deficit hyperactivity disorder (ADHD). In contrast, Melekoglu (2011) created an 18-week intervention which consisted of a daily structured reading program; though it showed improvement in the children's reading level it did not establish an increase in reading motivation.

How can these gaps be minimized? The intervention program "Joy of Reading" presents a model for helping pupils with learning disabilities to change their attitude towards reading and develop new reading habits.

\subsection{The Intervention Program: "The Joy of Reading"}

This intervention was specifically planned for children with learning disabilities. The broad theoretical and practical know-how of what characterizes children with reading disabilities was taken into consideration. The variety of difficulties that children with learning disabilities face was addressed. For example:

- Difficulties in attention were addressed by an array of short-term activities.

- Difficulties in perception were addressed by exposure to multi-sensory stimuli.

- Difficulties in processing were addressed by repetitive and structured activities.

- Difficulties in language were addressed by systematic exposure to new words and expressions.

The intervention necessitated holistic treatment which considered the strengths and capabilities of the child and worked with them. The intervention also considered the child's emotional and behavioral state. For this reason, an essential part of the program was based on displaying the literate products created by the child, thus building up a sense of personal competence and self-confidence. In order to reduce specific information-processing difficulties, the process was accompanied by numerous activities designed to improve memory, organization, systematic work, language and attention. All activities were intended to achieve the goal of improving perceptual capabilities by means of daily reading and writing activities.

The intervention program focused on exposing pupils with learning disabilities to stories and books using multiple intelligences. These intelligences reflected the structure of their individual language, their power of self-restraint, their expectations of others, cultural pressures, and accepted norms of thinking, leading them to act to solve problems or create a product (Chapman, 1993; Buschick et al., 2007). It also created diverse opportunities for encountering books and stories in an experiential, interesting and non-threatening manner. Differentiated instruction was implemented, challenging learners to use their individual capabilities, interests, and preferred styles of learning, thus maximizing each child's learning potential (Corley, 2005).

The intervention program consisted of nine activities which included: daily reading, a classroom library, storytelling and retelling, functional reading, serial stories, discovery reading, the accumulating principle, dialogue reading and post-reading activities .

\section{Aims and research hypothesis}

Previous studies established that young readers with high reading motivation enjoy reading, read frequently (Wang \& Guthrie, 2004), and express personal preference to reading (Guthrie \& Wigfield, 2000).

Therefore, the aim of the present study was to examine whether a prolonged intervention program results in creating a joy of reading among pupils with learning disabilities, which, in turn, generates greater reading motivation. This aim led to the following research question:

Does focused and prolonged exposure to the intervention program result in children having a greater joy of reading, 
measured as an increase in book preference reading quantity and reading quality, all in comparison to the control group?

\section{Method}

In the method section, we describe the subjects, intervention program, researchtools and data collection procedures.

\subsection{Subjects}

The research population consisted of 108 pupils (74 boys and 34 girls) aged 7-8, from 12 second grade special classes for pupils with learning disabilities in reading and writing, in several small towns adjacent to a large city in the northern part of Israel. All participants had been referred to these classes following a psychological diagnosis and in accordance with a decision made by a placement committee of the Ministry of Education. The children's IQ was normal. All participants were from similar socio-economic backgrounds.

The classes were randomly assigned to a research group and a control group. No significant differences were found in gender distribution within each of the groups $\left(\mathrm{x}^{2}=.35 \mathrm{p} . \mathrm{ns}\right)$. The current reading ability of all participants was found to be below the norm for their age; the pupils partially identified letters and struggled with slow and inaccurate phonological decoding of texts.

A RAVEN test was conducted in order to map the children's cognitive abilities. RAVEN is a language independent test (reading and writing skills) that measures the examinee's reasoning ability (or "meaning-making") which is often referred to as general intelligence (Raven,1936). The test is the most common and popular test administered to groups ranging from five year-olds to the elderly (Kaplan \& Saccuzzo, 2009). The test showed that the research group and the control group were nearly equal in this respect (research group: $\mathrm{M}=88.83 ; \mathrm{SD}=8.14$; control group: $\mathrm{M}=89.20 ; \mathrm{SD}=8.63$; $\mathrm{P}=$ n.c.; $\mathrm{t}=-.22$ ).

\section{2 "The Joy of Reading" Intervention Program}

The Joy of Reading intervention program was performed five days a week, for 45 minutes each day, during an entire school-year; the activities were systematically performed, and each session had fixed parts (daily reading: 15 minutes free reading followed by writing-after-reading) and variable parts (e.g. discovery reading, storytelling and retelling, functional reading etc.).

\subsubsection{Daily Reading}

The teacher scattered books on tables in the classroom appropriate for the students' level of reading, mostly with very little text (one or two sentences), and large illustrations that created anticipation about the written text, using pupils' prior knowledge. Each pupil kept a personal illustrated and decorated booklet. After 15 minutes of reading, they were asked to fill in a page in the booklet and write down the book's title, the author's name, the illustrator's name and one sentence about the book. The aim of the booklet was to encourage the pupils to read and relate to their reading book by writing a response. Once a month, the pupils were given a new booklet (Hopenwasser \& Noel, 2014). Daily reading served as the fixed-part activity of the intervention program.

\subsubsection{Classroom Library}

In each classroom a library was created consisting of children's newspapers, comics and jokes, various books, including poetry, story-books, fairy-tales, activity books such as cooking and arts \& crafts, encyclopedias and Bible stories. Different genres of a particular topic were presented, such as on the topic of "stones". The library included a story-book called "Stone Soup", a science book about stones and a science fiction book on the same topic. The classroom library was active all day long; the pupils could go to the library after they finished tasks, needed information, or as a relaxing activity. The pupils could also borrow books to take home by filling out a form and leaving it in the lending box. A library corner was dedicated to activity cards suggesting activities such as: Choose a character and write him/her a letter; What would you do if you were the hero?; Which character did you like?; Change the story's end; Continue the story etc. (Hopenwasser \& Noel, 2014).

\subsubsection{Storytelling and Retelling}

Each week the teacher performed collective in-class reading with the whole class implementing Slavin's model (1996) as follows: On the wall a poster that looked like a book jacket invited pupils to write on it the book's title, author's name, illustrator's name and new words that they had acquired from the story. Based on Whitehurst et al. (1991), in this way the teacher raised anticipation and curiosity before story-reading.

In the second part of the activity there was also interactive reading in which the pupils "lived" the story: they were asked to represent the heroes, speak for them, conduct discourse on their behalf, and write a letter or an advertisement about the story. In the final part of this activity, pupils were asked to respond in writing to questions like: "What would 
you do if...?" and "What could the hero have done instead of ...?" etc. The pupils were asked to react in writing to illustrations and were encouraged to write as much as they could.

In the third part of the reading activity, a review of the story's structure and central elements was conducted. In the fourth stage the story was reconstructed, developing pupils' awareness of the story's discourse schema (Peled, 1994; Berman \& Slobin, 1997; Katzenberger, 1997). The pupils were made aware of the structure: background, characters, plot, problem, resolution, and ending. The pupils repeated the story's structure and elaborated on the reasons, feelings and other solutions. They were asked to assess and judge the heroes and their actions, thus developing a critical point of view.

\subsubsection{Functional Reading}

The teacher systematically exposed the pupils to the various functions of reading. Each child was exposed to a text appropriate for his/her reading level.

The referential function: reading for obtaining information. The pupils worked on operative "how to" texts, such as: how does one bake a cake or build a flying model?

The connotative function: the pupils became aware of the communicative function used for attitude change. They learnt to differentiate between an announcement of an upcoming event and an advertisement; they created advertisements and announcements referring to the same topics.

The communicative function: The pupils learnt that written language enables them to maintain contact and transfer information, making the world a small village. They experienced writing and reading notices to parents, letters, greeting cards, telegrams, announcements, etc.

The expressive function: The pupils learnt to express themselves by writing a diary, a journal, using a complaint box, etc.

\subsubsection{Serial Story}

During the breakfast break the teacher read the pupils a serial story. Often, the pupils were intrigued and later looked up the story in the classroom library in order to continue reading it by themselves. This activity encouraged pupils to read and improve their decoding ability (Katzenberger, 1997).

\subsubsection{Discovery Reading - Interactive Book Reading}

Interactive book reading in early education was proved as a tool for stimulating acquisition of printed knowledge as well as oral language (Mol, Bus \& de Jong 2009).

The teacher began reading a story and stopped in a middle of a sentence asking the pupils to guess how to continue or end it, while encouraging them to use proper syntax and morphology. If an incorrect morphological suggestion was proposed (such as: "A child go?"), the teacher analyzed it with the pupils in order to detect the mistake. The teacher encouraged them to use their semantic knowledge schema in order to guess (anticipate) the story's continuation. For instance, if the sentence described Danny who went to eat at..., she tried to raise different options and direct the pupils to test and choose a plausible option where he might go to eat (Slavin, 1996).

\subsubsection{The Accumulating Principle}

Various repeating patterns were used, such as sound, word, line, verse. In this way the rhythmic-musical power of the experience was enhanced while lessening the child's anxiety by means of the familiar structure (Levin et al, 2007). One example for this is repetition of an anaphoric pattern:

"My friend Tin-tan,

No one has seen him yet,

No one has heard him yet,

My friend Tin-tan Tin-tan Tin-tan".

\subsubsection{Dialogue Reading}

In this domain the pupils were treated as active partners; they were asked questions while reading, referring to their comments even if they seemed irrelevant to the text; were asked to elaborate on other pupils' ideas, and to observe illustrations and central elements that may help their understanding of the story.

\subsubsection{Post-Reading Activities}

The pupils were asked to dramatize, create a dialogue, play socio-dramatic games, write letters to the story heroes, react to events, and participate in the plot by changing it. They were also asked to write a report about the book they read, 
meet writers, and prepare a "book market", a book exhibition and original illustrations.

\section{Program Assessment}

A successful intervention program is one whose implementation will result in the creation of a "joy of reading" which, in turn, will result in an increase in reading motivation (Wang \& Guthrie, 2004). Therefore, the intervention program "Joy of Reading" was assessed in three aspects, assuming:

- Book preference - a pupil who enjoys reading will prefer to read a book as a recreational activity and to receive a book as a present.

- Quantity of reading - a pupil who enjoys reading will read more.

- Quality of reading - a pupil who enjoys reading will elicit meaning more easily, and will process the book by performing content and characters analysis.

\subsection{Research Tools}

The "joy of reading" intervention program will be assessed using three measures: do the pupils in fact read more books, read at a better quality, and prefer reading over other leisure activities.

\subsubsection{Personal Preferences Questionnaire}

The questionnaire examined the pupils' preference of recreational activities in their leisure time. The questions aimed to identify pupils who preferred reading and served as nominal variables (Appendix 1).

Part a - Each pupil was asked in three separate questions, to choose a present from several options and tell what they like doing in their free time.

Part b - Amount of reading - aimed to check how many books the pupils have read. The question was meant to prevent biased responses since the pupils might answer that they prefer reading in order to please their teacher. Therefore, they were asked to mention what books they liked. The question was an open question enabling the pupils to answer in a free style, detailing book names or types of books. The next question asked them to list the books they had read in the last year, in order to ensure adequate reading quantity, and reading that was suited to their age.

The questionnaire was developed with the aid of an Israeli reading specialist. Expert validity was established by asking 10 parents, 10 teachers, 10 librarians and 66 students from the second grade to give their opinion of the questions (whether the questions examine personal preferences and to what extent they do so) and to suggest additional items for the questionnaire.

\subsubsection{List of Popular Books for Second Graders}

Each pupil was presented with a list of 10 popular books suited to their age, and asked to mark the books they had read. The task was followed with a comment stating that they would be asked to discuss the books. This was meant to direct the pupils to mark only books that they had actually read. The 10 books were selected for the list in the following manner: A list of 30 popular books was created by reading experts, combined with the Ministry of Education lists of recommended books. The list of 30 books was later presented to a validation group which consisted of three teachers, three librarians, three parents and three students. Using the validation group the 10 most popular books were chosen for the final list. The number of books the pupils recognized and/or read served as graded variables (Appendix 2).

\subsubsection{Quality of Reading Questionnaire}

This questionnaire was an adaptation of the pupils' independent work card index developed by Biderman (1983). The card index aimed to ensure profound and productive book reading. The card index was divided according to skill levels, beginning with external observation and ending with content comprehension. The items were chosen in order to examine the quality of the pupil's reading, such as ascertaining what the reader had assimilated from the book beyond the general content and characters descriptions. Each pupil was asked to choose a book from the list of popular books for second graders and describe its content and characters, what new things they had learned and if they would recommend this book to their friends and why.

These questions are an operative interpretation of the term "quality of reading" The questionnaire was distributed to 10 parents, 10 teachers and 10 librarians who were all asked to express their opinions as to the extent to which the questions actually check the quality of reading. They were also asked to make further suggestions regarding the structuring of the test. In the second stage a face validity test was conducted. Ten second graders were asked to respond to the questionnaire, say whether the scale was clear, whether the items were relevant to their world, and whether additional items were desired (Appendix 3). 


\subsection{Data Collection Procedures the Procedures of Assessing the Effectiveness of the "Joy Of Reading" Intervention Program Were:}

a) One on one matching was performed between the intervention group (6 classes) and the control group (6 classes) on cognitive ability (RAVEN test).

b) The intervention program was implemented in the research classes for one year.

c) At the end of the school year, the questionnaires concerning the enjoyment of reading were presented to all classes by a single tester. Testing was conducted at the same time of day in both groups.

d) In-depth semi-structured interviews were conducted with homeroom teachers (this paper will focus more on the quantitative data and less on the qualitative findings).

e) Analysis of data: In order to analyze differences between the research group and the control group, percentage and median frequencies were calculated to describe nominal and graded variables. Graded variables were calculated using the Mann-Whitney test when the distribution pattern was not normal. Differences among means were calculated using 2 tests.

\section{Results}

In the results, we aimed to answer the research question: Does focused and prolonged exposure to the intervention program result in children having a greater joy of reading, measured as an increase in book preference, reading quantity and reading quality, all in comparison to the control group?

Therefore, we describe the research findings in the aspects of book preference, quality of reading and quantity of reading.

\section{Experimental measures}

\section{Enjoyment of reading}

We assumed that the level of reading enjoyment manifested by the children in the research group would be higher than that of the control group. Reading enjoyment was established using the three aspects of the "Joy of Reading" assessment: 'Book Preference', 'Quality of Reading' and 'Quantity of Reading'. Inspection of the results shows that there were significant differences between the research group and the control groups in all three aspects.

\section{a. Book preference}

Testing the preference of reading books over other pastimes was performed in several ways:

I. Each pupil was asked to grade his/her liking of the following pastimes: reading a book, listening to a story, playing on the computer, watching television or playing. The responses were graded on a three level scale: $0=$ don't like, $1=$ like a little, $2=$ like a lot. The differences in grading were calculated by applying the Mann-Whitney U test. Figure 1 displays the results.

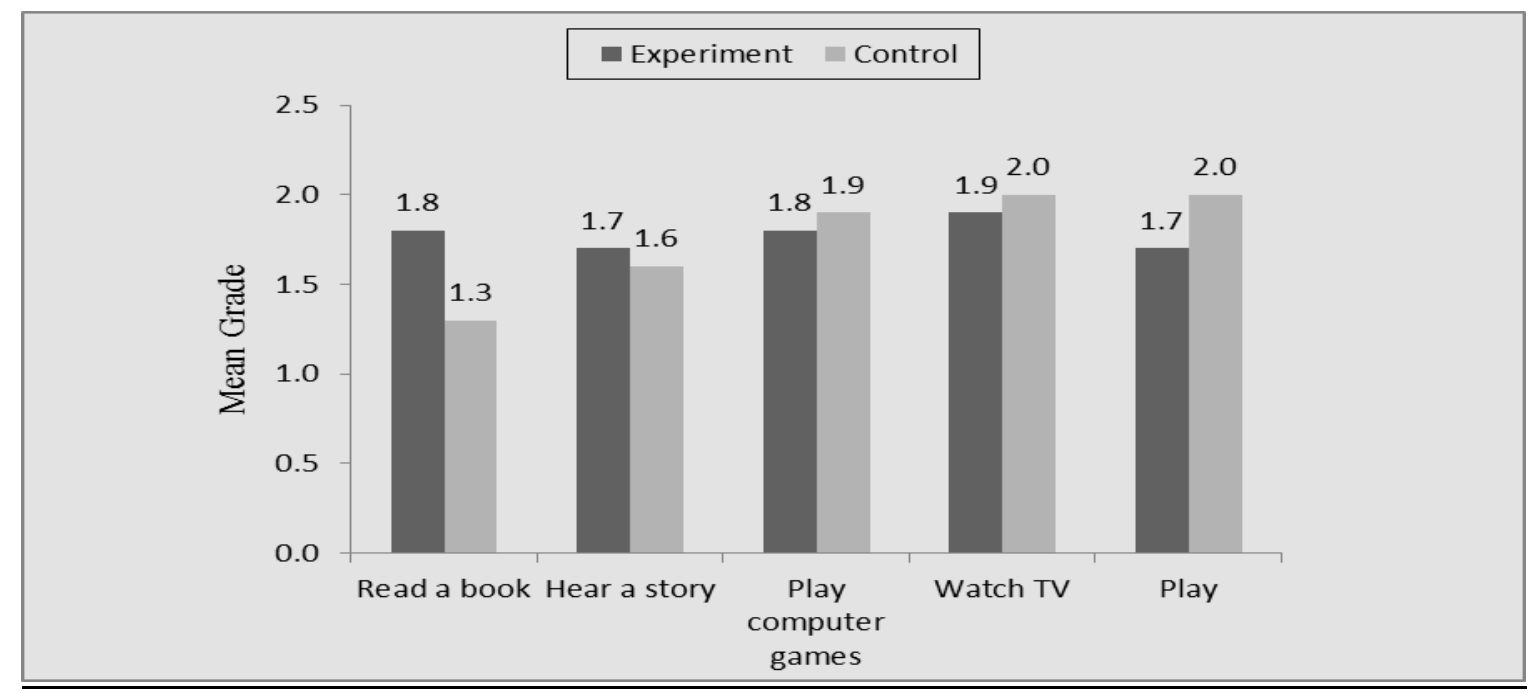

Figure 1. Preferred pastime (mean grades and significance $\mathrm{Z}$ test)

Figure 1 shows that the pupils of the research group prefer pastimes with a book $(p<.001)$, whereas the control group pupils prefer playing on the computer $(p<.05)$, watching television $(\mathrm{p}<.05)$ and playing $(p<.01)$. These differences were 
found to be significant. No difference was found between the two groups in liking to listen to a story.

II. The pupils were then asked what activity, from the list of activities mentioned in the previous question, they would choose if they had to choose only one. Figure 2 displays the findings.

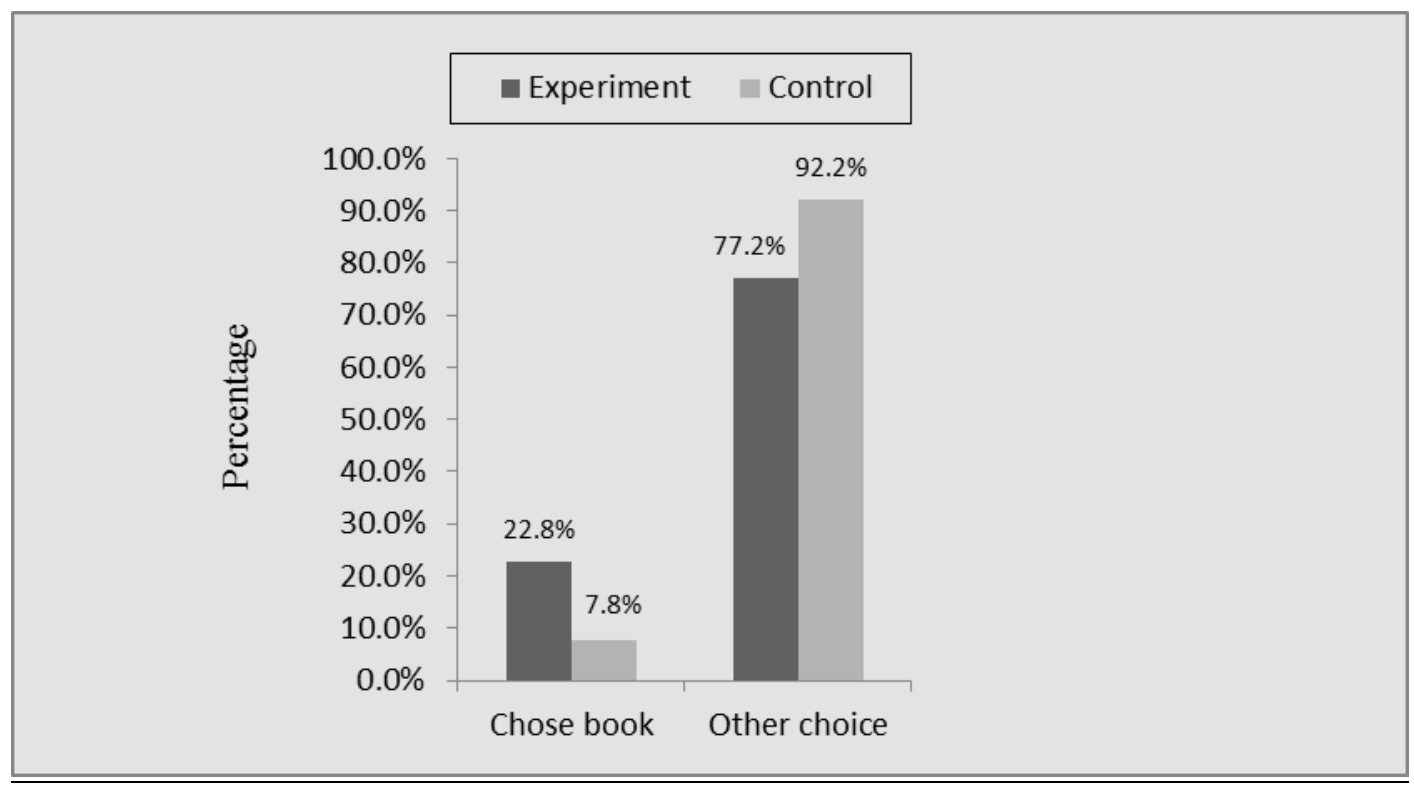

Figure 2. Books as a preferred pastime (percentage)

Figure 2 shows that approximately $23 \%$ of the pupils in the research group would prefer a book, compared with $8 \%$ in the control group $(\chi 2=4.78 ; p<.05)$.

III. The pupils were asked which item they would prefer as a gift. Figure 3 displays the findings.

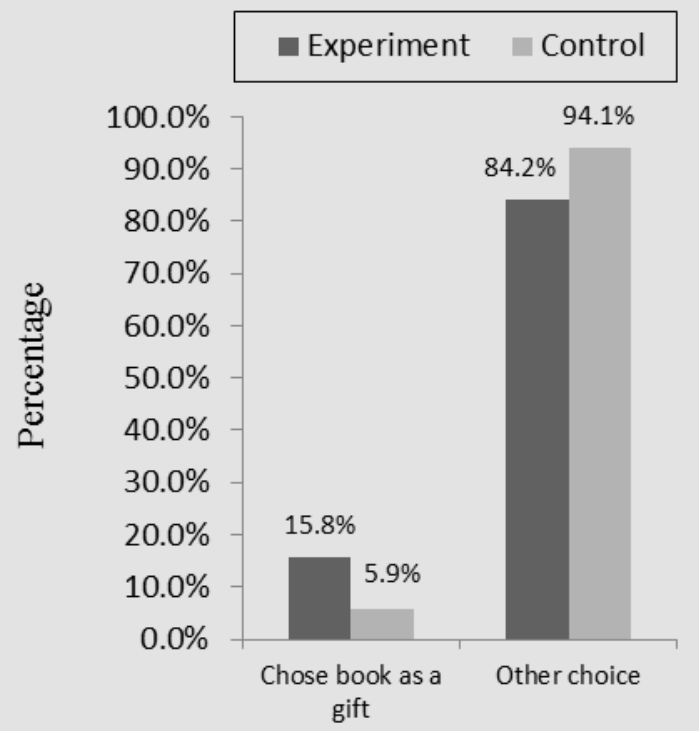

Figure 3. Books as gifts (percentage)

Figure 3 shows that an analysis of the pupils' answers to the question of what they would like to receive as a gift reveals a similar pattern among the answers of the pupils in the research group. Approximately $16 \%$ of the pupils in the research group stated that they would prefer a book as a gift, compared with $6 \%$ of the pupils in the control group. However, this difference was not found to be significant $(\chi 2=2.81 ;$ p.ns $)$. 
The pupils were asked to state their preferred spare-time activity. Figure 4 displays the results.

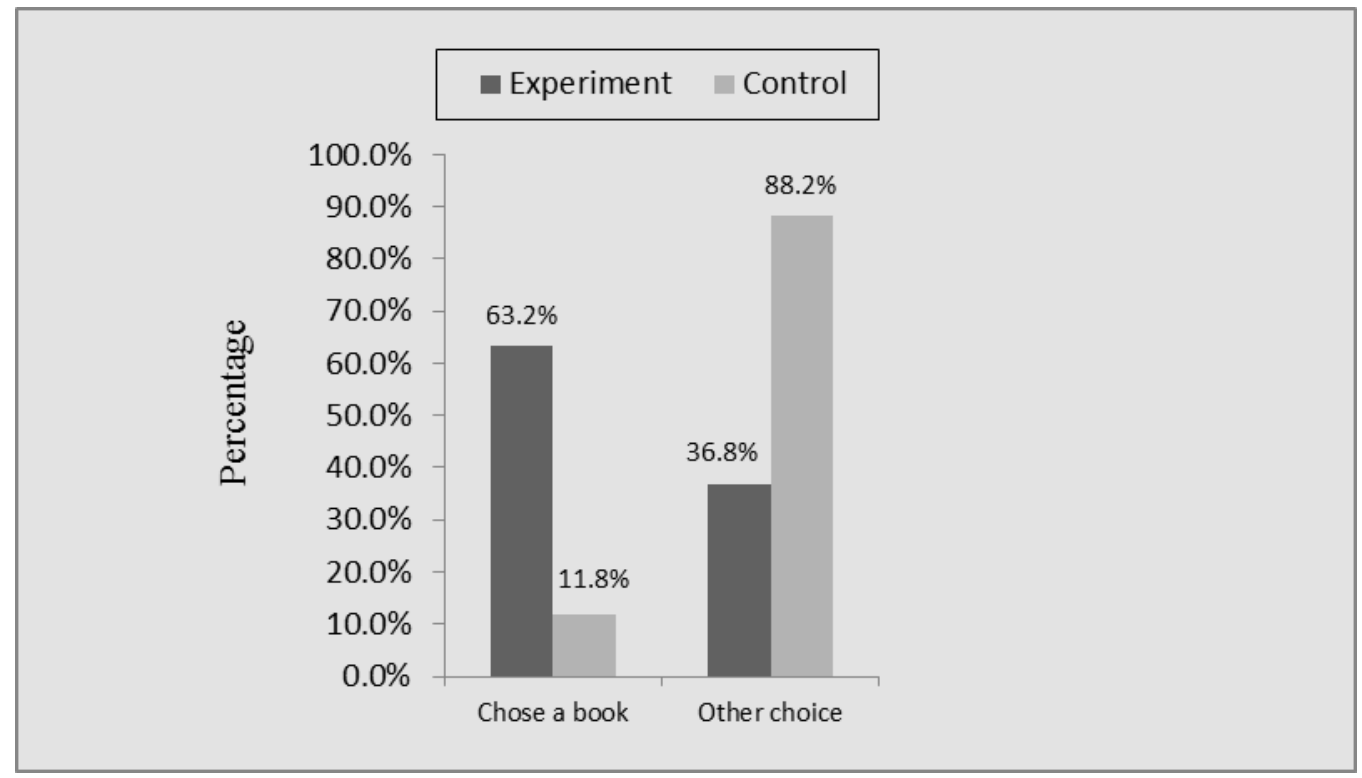

Figure 4. Preferred spare time activity (percentage)

Figure 4 shows that when asked what they would prefer to do in their spare time, $63.2 \%$ of the pupils in the research group said that they would prefer to read a book, compared with approximately $12 \%$ of the control group. This difference was found to be significant $(\chi 2=32.37 ; p<.001)$.

In all four indices the pupils of the research group preferred books significantly over other pastimes.

In order to validate this conclusion, a preference grade was compiled, consisting of the four variables surveyed so far. The grade range is $0-5$, with 0 signifying that the pupil never chose a book in any of the questions, and 5 signifying that $\mathrm{s} / \mathrm{he}$ chose a book in all questions. The findings show a mean preference grade of 2.79 for the research group (median $=$ 3.0 ), compared with a mean of 1.53 (median $=2.0$ ) in the control group. Due to the distribution pattern of this variable, an a-parametric test was performed to examine the differences between the groups (the Mann-Whitney $\mathrm{U}$ test). The gap in book preference was found to be significant $(Z=-5.28 ; \mathrm{p}<.001)$.

\section{b. Quantity of reading}

The grade for quantity of reading was calculated in two steps:

Step I: the pupils were asked three questions about the number of books they had read:

1. Please write down the names of a book you like.

(research group mean $=2.94 ;$ control group mean $=1.29 ; \mathrm{t}=6.88 ; \mathrm{p}<.001)$.

2. Which books do you remember reading during the current year?

(research group mean $=3.47$; control group mean $=1.10 ; \mathrm{t}=9.97 ; \mathrm{p}<.001)$.

3. Please circle the name of the books which you have read out of the following list. (research group mean $=$ $4.89 ;$ control group mean $=2.41 ; \mathrm{t}=8.13 ; \mathrm{p}<.001$ ).

The quantity of books mentioned by the children in the research group was significantly higher than the quantity of books specified by the control group in all three indices.

Step II: A total grade of quantity of reading was calculated using the three aforementioned indices.

Table 1 presents the differences in quantity of reading between the research group and the control group. 
Table 1. Differences in quantity of reading between the research group and the control group (means, standard variance, minimum, maximum and $\mathrm{Z}$ test)

\begin{tabular}{llllll}
\hline & Mean & Median & Min. & Max & Z \\
\hline Research & 11.61 & 11.50 & 6 & 23 & $-8.26^{* * *}$ \\
Control & 4.75 & 5.00 & 1 & 9 & \\
\hline $0-40$ & & & & &
\end{tabular}

Range $\overline{0-40}$

The table shows that quantity of reading in the research group (11.6) is significantly higher $(p<.001)$ than quantity of reading in the control group $(4.75)$.

\section{Quality of Reading}

Quality of reading was tested by the manner in which the pupils analyzed one of the books they had read. The pupils' descriptions of the characters were evaluated according to the dimensions of credibility and precision and depth and range of description. The pupils were also asked to summarize the content of the story. Figure 5 displays the findings in the five areas which were tested.

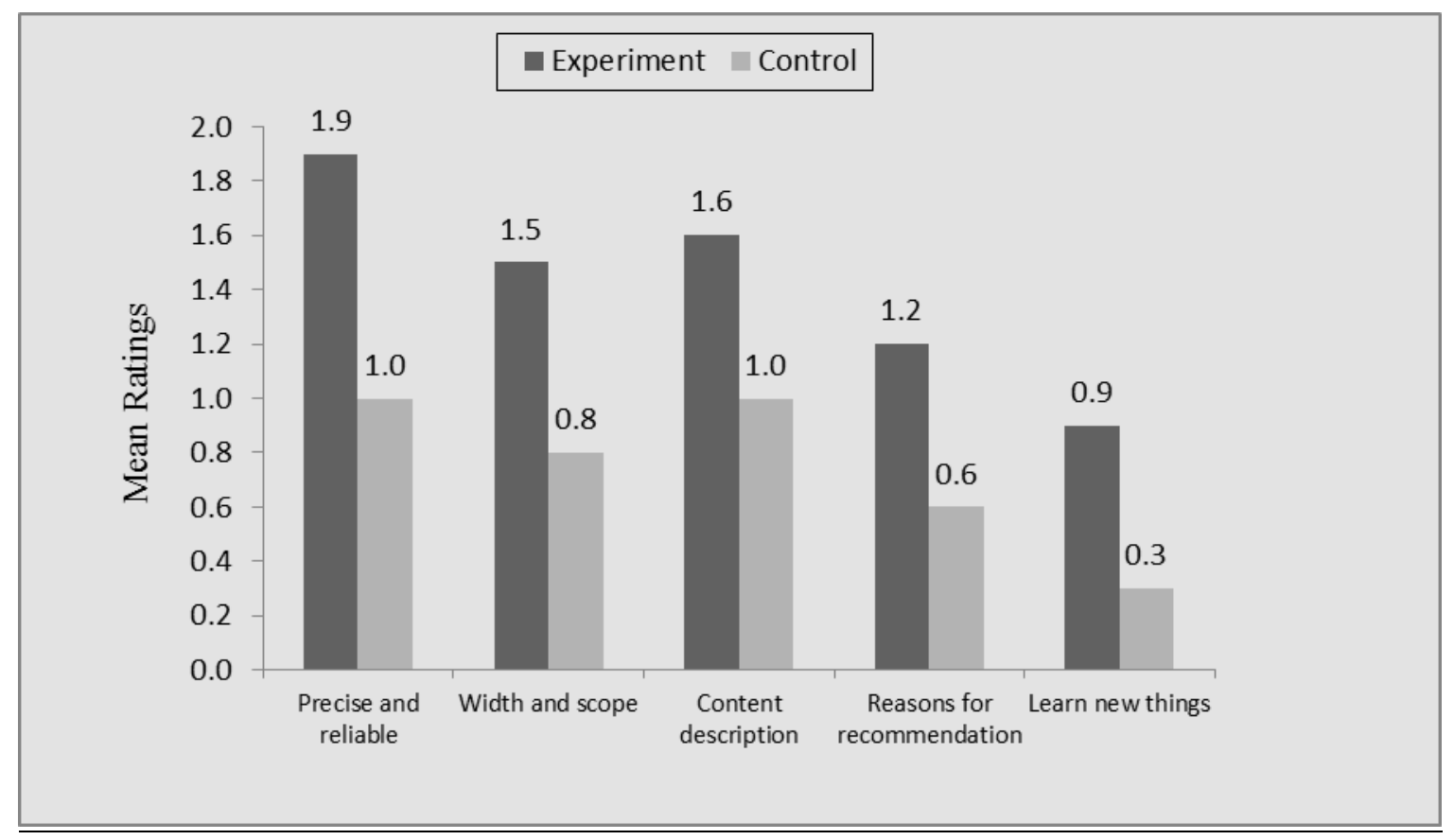

Figure 5. Quality of Reading (mean ratings $-\mathrm{Z}$ test)

Figure 5 shows that the rating of the research group's quality of reading is significantly higher than that of the control group in all parameters $(p<.001)$. In order to validate this finding, an over-all reading grade was calculated. This grade constitutes the summation of the five indices of quality of reading. Hence, the range of this new variable is 0-5. Table 2 presents the results.

Table 2. Differences in quality of reading rating between the research group and the control group

\begin{tabular}{llllll}
\hline & Mean & Median & Min. & Max & Z \\
\hline Research & 6.96 & 7.00 & 3 & 10 & $* * *-7.14$ \\
Control & 3.61 & 4.00 & 0 & 9 & \\
\hline
\end{tabular}

Range $0-10$

$* * * \mathrm{p}<.001$

The table shows that the quality of reading of the pupils in the research group significantly exceeds that of the control 
group.

Summarizing the above results, it seems that a significant change took place among the pupils in the research group compared to the control group. The pupils in the research group enjoyed reading more, preferred reading books in their spare time, and their quality of reading was higher than that of the control group.

\section{Discussion}

The results of this study reflected the fact that pupils who were exposed to the intervention program: "The Joy of Reading" experienced a significant increase in reading quality, reading quantity and preferred reading books over other leisure activities in comparison to pupils who were not exposed to the program. These findings corroborate previous findings regarding the causality between plentiful reading and reading motivation (Guthrie, 2008 ; Guthrie \& Humenich, 2004).

Previous reading-instruction intervention programs failed to show that an increase in reading achievements led directly to an increase in reading motivation among learning-disabled children (Melekoğlu \& Wilkerson, 2013). In contrast, our study did not deal with reading instruction, but with enjoyable reading activities that led to an improvement in reading quantity, reading quality and the preference of reading books over other activities - all of which are indications of an increase in reading motivation.

Our findings show that the "Joy of Reading" intervention program created a variety of opportunities for a positive experience in literacy and related activities, such as book reporting, role playing and changing parts of the story. These literacy activities enabled pupils to develop, enrich and exercise their story schema knowledge as expressed by their ability to reconstruct the story and analyze the main character. These activities also enhanced their feelings of success and enjoyment in dealing with stories and books. Above all, the intervention program created a community of readers who read significantly more.

This was the beginning of a learning process, which helped pupils use stories for different purposes and develop their schema story (Mol et al., 2009). The "Joy of Reading" intervention program created an environment that was planned, structured and clearly defined. Such an environment helped pupils who had a history of failures in literacy to experience a protected environment that led them through "small successes" in dealing with reading books and stories, accumulating positive experiences, and in due course generating a sense of reading ability and satisfaction.

Homeroom teachers described the intervention process, on an axis that moved from reading avoidance and disruptive behavior to choosing reading as a preferred activity. "I brought books to the classroom, the children thought it was anarchy and they can do anything they please. Slowly they understood the framework and its boundaries" (teacher no.1). "I did not have a wasted moment; once the children finished their work they started playing. Now, when they are finished, without asking, they run to the books... it was not like this before" (teacher no.5).

Pupils' willingness to invest in the long process of improving their reading was produced by a gradual track consisting of short, small, achievable steps. Starting with the present abilities of each pupil, each success was rewarded and encouraged. The accomplishments allowed the pupils to slowly but surely climb up Vygotsky's scaffolds (Vygotsky, 1978 ) with the mediation of the teacher. This environment provided activities that did not confront the pupils with their difficulties, while not giving up on them. In this manner, the child's sense of competency and faith in him/herself as an independent reader was developed (Anderman et al., 2004; Guthrie, Alao, \& Rinehart, 1997; Howse et al., 2003).

Our findings indicate that the pupils did not come with prior knowledge on story schema, which means that they acquired it during the intervention program. Story schema discourse is created through reading, listening and creating stories. Continuous interaction with story schema made it familiar, automatic and safe to use, serving as an incentive to reading activities and reading enjoyment.

Thus, the mutual enrichment these activities conveyed generated interest reduced the levels of anxiety and reluctance to read, and inspired pupils to read books together and individually. It seems that the process broke the failure-and-avoidance circle, and enabled growth.

\section{Limitation of the Study}

The innovation effect is well known in literature and may affect the teachers, and indirectly, the children, at least temporarily. Therefore, a one-year experience with a new method, accompanied by a research project, may be misleading. The impressive achievements may result from the teachers' initial enthusiasm, and may not express a fundamental change. The children may return from their two-month summer vacation and regress to their former level. The proposed method seems to achieve a profound meta-cognitive change, anticipating minor regression due to lack of practice during the summer. However, this point requires further research.

It is also necessary to conduct a follow-up study with teachers to determine whether the enthusiasm, induced by the 
innovation effect, would dissipate, or, on the contrary, the experience would promote personal and professional enrichment, encouraging further improvement in the years to come.

\section{Conclusions}

This study shows that enhancing reading enjoyment in classes of pupils with learning disabilities requires a joint and holistic effort, by creating a supportive environment. The teachers act as mediators who make things easier for pupils and convey a message that a reading activity can be fun and achievable. Continuing this line of thought, this study also shows that children with learning disabilities need teacher mediation and support in order to achieve meaningful reading. The teacher's mediating activities have to focus on directing children's attention to learning opportunities, enabling them to investigate, discover, deduce, and create a cognitive category through generalization and conceptualization.

Reading enjoyment is a continuous activity that should be nurtured and maintained as a "lifelong habit". Therefore, it should be assessed again after a period of time in order to examine the intervention's effect and adjust the environment if necessary. This means that the environment has to create continuous conditions that enhance both reading activities and teacher supportive mediation.

Recommended steps to promote reading enjoyment:

- The teacher must be convinced and committed to promoting reading enjoyment by creating a supportive and structured environment.

- Time should be allocated each day for reading activities in a structured pattern (such as choosing a book, reading, submitting a written report, etc.).

- A rich classroom library that includes various genres and levels is needed.

- There should be several options for reading activities, and instructional guidance simultaneously.

- Reading activities should be enjoyable and mediated in order to generate reading motivation.

\section{References}

Allington, R. L., McGill-Franzen, A. M., Camilli, G., Williams, L., Graff, J., Zeig, J., . . . Nowak, R. (2010). Addressing summer reading setback among economically disadvantaged elementary students. Reading Psychology, 31(5), 411-427. http://dx.doi.org/10.1080/02702711.2010.505165

Anderman, E. M., Noar, S., Zimmerman, R. \& Donohew, L. (2004). The need for sensation as a prerequisite for motivation to engage in academic tasks. In M.L. Maehr \& P. R. Pintrich (Eds.). Advances in motivation and achievement (Vol. 13: Motivating students, improving schools: The legacy of Carol Midgley, pp. 1-26). Greenwich, CT: JAI Press.

Aram, D., \& Levin, I. (2002). Mother-child joint writing and storybook reading: Relations with literacy among low SES kindergartners. Merrill-Palmer Quarterly, 48(2), 202-224. http://dx.doi.org/10.1353/mpq.2002.0005

Berman, R. A., \& Slobin, D. I. (1997). Different ways of relating events in narrative: A crosslinguistic and developmental study. Hillsdale, NJ: Erlbaum.

Biderman, G. (1983). Cards for independent work on the improvement of reading effectivity (master thesis), Haifa University, Israel. (Hebrew)

Blum-Kulka, S., Gerber, R., Marom I., \& Aharoni, B (2003). Lingual education: Hebrew - language, literature and culture: Studies program for elementary school. Jerusalem, Ministry of Education. (Hebrew)

Bus, A. G., van Ijzendorn, M. H., \& Pellegrini, A. D. (1995). Joint book reading makes for success in learning to read: A meta-analysis on intergenerational transmission of literacy. Review of Educational Research, 65(1), 1-21

Buschick, M. E., Shipton, T. A., Winner,L. M., \& Wise, M. D. (2007). Increasing reading motivation in elementary and middle school through the use of multiple intelligences: An Action Research Project (master thesis). Saint Xavier University \& Pearson Achievement Solutions, Chicago, Illinois.

Chapman, C. (1993). If the shoe fits...how to develop multiple intelligences in the classroom. Arlington Heights, Ill.: Skylight Professional Development.

Clark, C., \& Rumbold, K. (2006). Reading for pleasure: A research overview. National Literacy Trust.

Clark, C., \& Foster, A. (2005). Children's and young people's reading habits and preferences: The who, what, why, where and when. London: National Literacy Trust.

Clark, C., \& Akerman, R. (2006). Social inclusion and reading: An exploration. London: National Literacy Trust.

Corley, M. A. (2005). Differentiated instruction: Adjusting to the needs of all learners. Focus on Basics, 7(C), 13-16. 
Retrieved from http://www.ncsall.net/fileadmin/resources/fob/2005/fob_7c.pdf

Dungworth, N., Grimshaw, S., McKnight, C., \& Morris, A. (2004). Reading for pleasure?: A summary of the findings from a survey of the reading habits of year 5 pupils. New Review of Children's Literature and Librarianship, 10, 169-188. http://dx.doi.org/10.1080/1361454042000312284

Epstein \& Yanai (2011). Is it possible to "catch the flu" of the love of reading? Meidaat Journal of Librarianship, 7, 57-64.

Gambrell, L. (2011). Seven rules of engagement: What's most important to know about motivation to read. The Reading Teacher, 65(3), 172-178. http://dox.doi.org/10.1002/TRTR.01024

Guthrie, J. T. (Ed.). (2008). Engaging adolescents in reading. Thousand Oaks, CA: Corwin Press.

Guthrie, J. T., Alao, S., \& Rinehart, J. M. (1997). Engagement in reading for young adolescents. Journal of Adolescent \& Adult Literacy, 40(6), 438-446.

Guthrie, J. T., \& Humenich, N. M. (2004). Motivating students to read: Evidence for classroom practices that increase reading motivation and achievement. In. P. McCardle \& V. Chhabra. (Eds.), The voice of evidence in reading research (pp. 329-354). Baltimore: Brookes Publishing.

Guthrie, J. T., \& Wigfield, A. (2000). Engagement and motivation in reading. In M. L. Kamil, P. B. Mosenthal, P. D. Pearson, \& R. Barr (Eds.), Handbook of reading research (Vol. 3, pp. 403-422). New York: Erlbaum.

Hopenwasser, C. B., \& Noel, A. M. (2014). Tackling Text Complexity With Your Classroom Library. Kappa Delta Pi Record, 50(2), 81-84.

Howse, R. B., Lange, G., Farran, D. C., \& Boyles, C. D. (2003). Motivation and self-regulation as predictors of achievement in economically disadvantaged young children. Journal of Experimental Education, 71(2), 151-174. http://dx.doi.org/10.1080/00220970309602061

Kaplan, R. M., \& Saccuzzo, D. P. (2009). Psychological testing: Principles, applications, and issues (7th ed.). Belmont, CA: Wadsworth.

Katzenberger, A. (1997). The development of the ability to tell a story to a series of pictures. Helkat Lashon, 24, 61-79. (Hebrew)

Levin, I. (2007). The role of Hebrew letter names in early literacy: The case of nulti-phonemic acrophonic names. Journal of Experimental Child Psychology, 98(4), 193-216.

Levin, I., \& Aram, D. (2012). Mother-child joint writing and storybook reading and their effects on kindergartners literacy: An intervention study. Reading and Writing, 25, 217-249. http://dx.doi.org/10.1007/s11145-010-9254-y

Levin, A., Svardalov, A., Abu-Rakva, S., Bab, Z., Bukshpen, A., Baron, A., . . . Teomim, S. (2007). Reading and writing infrastructure: Studies program for kinder garden. Jerusalem: Ministry of Education. (Hebrew)

Melekoglu, M. A. (2011). Impact of motivation to read on reading gains for struggling readers with and without learning disabilities. Learning Disability Quarterly, 34(4), 248-261. http://dx.doi.org/10.1177/0731948711421761

Melekoğlu, M. A., \& Wilkerson, K. L. (2013). Motivation to read: How does it change for struggling readers with and without disabilities? International Journal of Instruction, 6(1), 77-88.

Memiş, A., \& Bozkurt, M. (2013). The relationship of reading comprehension success with metacognitive awareness, motivation, and reading levels of fifth grade students. Educational Research and Reviews, 8(15), 1242-1246. http://dx.doi.org/10.5897/ERR2013.1544

Israel's Ministry of Education (2000). Adaptations of matriculation exams for students with learning disabilities in high schools. Director General's Code of Rules and Regulations, 9(a).

Mol, S. E., \& Bus, A. G. (2011). To read or not to read: A meta-analysis of print exposure from infancy to early adulthood. Psychological Bulletin, 137(2), 267-296. http://dx.doi.org/10.1037/a0021890.

Mol, S. E., Bus, A. G., \& de Jong, M. T. (2009). Interactive book reading in early education: A tool to stimulate print knowledge as well as oral language. Review of Educational Research, 79(2), 979-1007. http://dx.doi.org/10.3102/0034654309332561

Mullis, I., Martin, M., Kennedy, A. M., \& Foy, P. (2007). IEA's progress in international reading literacy study in primary school in 40 countries. Chestnut Hill, MA: TIMSS \& PIRLS International Study Center, Boston College.

Peled, N. (1994). Spoken language and written language in children from the third grade to the ninth grade (doctoral dissertation), The Hebrew University of Jerusalem, Israel. (Hebrew) 
Raven, J. C. (1936). Mental tests used in genetic studies: The performance of related individuals on tests mainly educative and mainly reproductive (MSc thesis), University of London.

Serpell, R., Baker, L., \& Sonnenschein, S. (2005). Becoming literate in the city: The Baltimore early childhood project. Cambridge: Cambridge University Press.

Slavin, R. E. (1996). Research on cooperative learning and achievement: What we know, what we need to know. Contemporary Educational Psychology, 21(1), 43-69. http://dx.doi.org/10.1006/ceps.1996.0004

Smith, F. (1990). To think. New York: Teachers College Press.

Vygotsky, L. (1978). Mind in society: The development of higher psychological processes. Cambridge MA: Harvard University Press.

Wang, J. H. Y., \& Guthrie, J. T. (2004). Modeling the effects of intrinsic motivation, extrinsic motivation, amount of reading, and past reading achievement on text comprehension between U.S. and Chinese students. Reading Research Quarterly, 39(2), 162-186.

Whitehurst, G. J., Fischel, J. E., Lonigan, C. J., Valdez-Menchaca, M. C., Arnold, D. S., \& Smith, M. (1991). Treatment of early expressive language delay: If, when and how. Topics in Language Disorders, 11(4), 55-68.

Witt, S. D. (2000). The influence of peers on children's socialization to gender roles. Early Child Development and Care, 162, 1-7. http://dx.doi.org/10.1080/0300443001620101.

Zentall, S. S., \& Lee, J. (2012). A reading motivation intervention with differential outcomes for students at risk for reading disabilities, ADHD, and typical comparisons: “Clever Is and Clever Does". Learning Disability Quarterly, 35(4), 248-259. http://dx.doi.org/10.1177/0731948712438556

\section{Appendix A}

\section{Personal Preferences Questionnaire.}

1. How much do you like the following pastimes?

\begin{tabular}{|l|l|l|l|}
\hline Reading a book & Not at all & A little & Very much \\
\hline Watching TV & Not at all & A little & Very much \\
\hline Playing outside & Not at all & A little & Very much \\
\hline Listening to a story & Not at all & A little & Very much \\
\hline Computer games & Not at all & A little & Very much \\
\hline
\end{tabular}

b. If you had to choose one of the pastimes mentioned in question 1a above, which would you choose?

2. Which of the following would you like as a gift? Please circle one item only.

\begin{tabular}{|l|l|}
\hline a. A new computer game & d. A remote control toy car \\
\hline b. A new book & c. A disk \\
\hline c. A bicycle & \\
\hline
\end{tabular}

3. What do you like to do in your spare time?

4. Which are your favorite books?

5. Which books do you remember reading this year? 


\section{Appendix B}

\section{List of popular books for second graders}

Name Homeroom teacher School

Book list: Please circle only books which you have read by yourself, because you will be asked to tell what each book is about.

\begin{tabular}{|c|c|c|c|}
\hline Example: Hot Corn & Miriam Roth & (Poalim Publishers) & $\begin{array}{l}\text { I read it by myself__ } \\
\text { I have not read it }\end{array}$ \\
\hline 1. Yael's House & Miriam Roth & (Poalim Publishers) & $\begin{array}{l}\text { I read it by myself_- } \\
\text { I have not read it }\end{array}$ \\
\hline $\begin{array}{l}\text { 2. The Egg that Wore a } \\
\text { Costume }\end{array}$ & Dan Pegis & $\begin{array}{l}\text { (Am Oved } \\
\text { Publishers) }\end{array}$ & $\begin{array}{l}\text { I read it by myself_- } \\
\text { I have not read it }\end{array}$ \\
\hline 3. Where is Pinuki & Arik Heal & $\begin{array}{l}\text { (Schoken } \\
\text { Publishers) }\end{array}$ & $\begin{array}{l}\text { I read it by myself__ } \\
\text { I have not read it }\end{array}$ \\
\hline $\begin{array}{l}\text { 4. There's a Mouse in the } \\
\text { House }\end{array}$ & Mirik Snir & (Poalim Publishers) & $\begin{array}{l}\text { I read it by myself__ } \\
\text { I have not read it }\end{array}$ \\
\hline 5. Alone on the Mat & $\begin{array}{l}\text { Brian } \\
\text { Wildersmith }\end{array}$ & $\begin{array}{l}\text { (Hakibbutz } \\
\text { Hameuhad) }\end{array}$ & $\begin{array}{l}\text { I read it by myself__ } \\
\text { I have not read it }\end{array}$ \\
\hline 6. Pretzel (Hebrew: Beigele) & Margaret Rey & $\begin{array}{l}\text { (Hakibbutz } \\
\text { Hameuhad) }\end{array}$ & $\begin{array}{l}\text { I read it by myself__ } \\
\text { I have not read it }\end{array}$ \\
\hline 7. Oren's Turtle & Mira Meir & $\begin{array}{c}\text { (Keter Li } \\
\text { Publishers) }\end{array}$ & $\begin{array}{l}\text { I read it by myself__ } \\
\text { I have not read it }\end{array}$ \\
\hline 8. Tom, the Blue Cat & Yafa Telerk & $\begin{array}{l}\text { (Noga Kat } \\
\text { Publishers) }\end{array}$ & $\begin{array}{l}\text { I read it by myself__ } \\
\text { I have not read it }\end{array}$ \\
\hline $\begin{array}{l}\text { 9. The Elephant that wanted to } \\
\text { be the most.. }\end{array}$ & Paul Kor & $\begin{array}{l}\text { (Zmora Bitan } \\
\text { Publishers) }\end{array}$ & $\begin{array}{l}\text { I read it by myself_- } \\
\text { I have not read it }\end{array}$ \\
\hline 10. One Fine Morning & Ora Eyal & (Poalim Publishers) & $\begin{array}{l}\text { I read it by myself__ } \\
\text { I have not read it }\end{array}$ \\
\hline
\end{tabular}




\section{Appendix C}

\section{Quality of reading questionnaire}

Name

Homeroom teacher School

Write about one of the books which you have circled in the questionnaire.

a. The title of the book b. Author

c. Who is the story/poem about?

d. Tell the contents of the story/poem briefly.

e. Would you recommend this book to your friends?

Yes / No

Why, or why not?

f. Did you learn something new from the book?

What did you learn?

\section{(cc) $\mathrm{BY}$}

This work is licensed under a Creative Commons Attribution 3.0 License. 